\title{
EVALUATION OF HEADACHE INTENSITY IN MIGRAINOUS PATIENTS WITH VISUAL HANDICAP THROUGH THE TACTILE ANALOGICAL SCALE (TAS)
}

\author{
Elcio Juliato Piovesan, Marcos Christiano Lange, Pedro André Kowacs, \\ Carlos Pacheco, Lineu Cesar Werneck
}

\begin{abstract}
The tactile analogue scale (TAS) was elaborated to be used in blind subjects or those who can not use the vision during their crises. The objective of this study was to characterize, from TAS, the architecture of migraine attacks in subjects with visual disability. For that, 11 migrainous with visual disturb (MVD) subjects were studied and 22 migrainous subjects with no visual disability as a control group. All patients fulfilled the criteria for migraine and the patients of the group studied showed visual acuteness less than 20/200. To evaluate the results, the patients of the group MVD were subdivide within two groups, according to their visual acuteness: subgroup $A$ subjects with subnormal vision and subgroup $B$ amaurotic ones. In subgroup $A$ measurement 46 attacks with average of the migraine attacks of the $56.50 \mathrm{~mm}$, in the subgroup B 45 attacks with average of the $59.58 \mathrm{~mm}$ and in the control group 92 attacks with average of the $49.88 \mathrm{~mm}$. When subgroup B and control group were compared there was a significant statistic difference $(p=0.022)$. Through these outcomes we can observe that the migrainous subjects with no visual afference show a higher pain intensity during the migraine crises comparing to those subjects with no visual handicap. The study suggests that, as in other forms of sensibility, the total visual loss can also interfere in the nociceptive control of the pain during the migraine attacks.
\end{abstract}

KEY WORDS: analogue scale, intensity, migraine, pain, visual acuteness.

Comportamento das crises de migrânea em pacientes com deficiência visual, utilizando a escala analógica táctil para a dor

\begin{abstract}
RESUMO - A escala analógica táctil para dor (TAS) foi elaborada para ser utilizada em cegos ou em indivíduos que não podem utilizar a visão durante suas crises. O objetivo deste estudo foi caracterizar, a partir da TAS, a arquitetura das crises de migrânea em indivíduos portadores de deficiência visual. Foram estudados 11 pacientes com deficiência visual e migranosos (DVM) e, como controle, 22 pacientes migranosos sem deficiência visual. Todos os pacientes preenchiam os critérios para migrânea e os pacientes do grupo DVM apresentavam acuidade visual menor que 20/200. Para avaliação dos resultados, os pacientes do grupo DVM foram separados em dois subgrupos: subgrupo $A$, pacientes com visão subnormal e o subgrupo $B$, pacientes amauróticos. No subgrupo A avaliamos 46 ataques com intensidade média das crises de cefaléia de $56,50 \mathrm{~mm}$; no subgrupo $B$ foram avaliados 45 ataques com média de 59,58 mm; no grupo controle 93 ataques com média de 49,88 mm segundo a TAS. Quando comparados o subgrupo B e o grupo controle, ocorreu diferença estatísticamente significativa $(p=0,022)$. Através destes resultados, podemos observar que os pacientes migranosos sem aferências visuais apresentam maior intensidade de dor durante as crises de migrânea em relação a pacientes sem deficiência visual. 0 estudo sugere que, como em outras formas de sensibilidade, a perda visual total pode interferir nos controles nociceptivos da dor.
\end{abstract}

PALAVRAS-CHAVE: dor, escalas analógicas, intensidade, migrânea, perda visual.

The evaluation of pain in subjects with headache, during scientific studies or clinical practice, can be carried out by different methods. The analogue scales constitute one of the principal ones, when the studies require sharp measurements of the pain and its influence on the functional capacity ${ }^{1}$. Piovesan et al. have structured and tested in subjects with normal vision a new scale named Tactile Analogue Scale for pain (TAS) ${ }^{2}$. Although it is addressed for patients with visual loss or for those ones who can not use the

Unidade de Cefaléia, Especialidade de Neurologia do Departamento de Clínica Médica do Hospital de Clínicas da Universidade Federal do Paraná (UFPR), Curitiba PR, Brasil.

Received 12 February 2001, received in final form 6 June 2001. Accepted 12 June 2001.

Dr. Elcio Juliato Piovesan - Serviço de Neurologia, Hospital de Clínicas da UFPR - Rua General Carneiro 181 / 12 andar - 80060-900 Curitiba PR - Brasil.FAX 5541264 3606.E-mail: piovesan@avalon.sul.com.br 
vision during clinical essays, this scale has never been tested in patients with such characteristics.

In this study, the authors intend to evaluate the TAS effectiveness on patients with visual deficiency during their migraine attacks, and so characterizing the migraine attacks in patients without visual afferences.

\section{METHOD}

\section{Subjects group study}

Eleven visual handicapped patients (median age 27.9 years old; 10 female and 1 male) with visual handicap that filled the International Headache Society's diagnostic criteria for migraine were evaluated ${ }^{3}$. The patients were divided in two groups according to their deficiency degree ${ }^{4}$ : the subgroup A (five subnormal vision) and subgroup B (six amaurotic patients). The patients of the subgroup B were dexterous and have used in average the Braille's reading for four hours daily in the last two years. The visual deficiency origin was neoplasic in three patients; cataract, pigment retinose in one; association of congenial cataract and rubella in one; association of glaucoma and cataract in one; and association of cataract and retina misplacing in one patient. Three patients ignored the cause of their visual handicap. No one had ophtalmologics disturbs that could provocate pain or influence intensity of the migraine crises. The subgroup A showed an average of 25.8 \pm 11.7 years old, the visual disability stopped increasing at 14.4 years and have remained stable for the last 11.4 \pm 10.4 years. Subgroup B showed an average age $29.6 \pm$ 4.9 years old, amaurosis started at $9.8 \pm 11.3$ years old (two of the patients were born amaurotic) and the average time duration of the amaurotic was $19.8 \pm 10.2$ years.

\section{Subjects group control}

Twenty two dextrous migraine patients with normal vision, 13 female $(32 \pm 2.3$ years old) and 9 male $(23 \pm$ 1.3 years old) were followed for 30 days with the same orientations used for the research patients. As the control group was formed by patients with normal vision, the same ones were orientated to fulfil TAS with close eyes and afterwards fulfil visual analogic scale (VAS) to conform the Piovesan's studies².

\section{Methods}

TAS was formed by 5 pages in Braille, containing the first one instruction to fulfil the scale. The other four pages showed 31 divisions composed by lines in high relief measuring $100 \mathrm{~mm}$. These lines were constituted by points in high relief, in a total 12 points intercalated by normal spaces (low relief) (Fig 1). Before the line there was, in Braille, the expression "No Pain" followed by $15 \mathrm{~mm}$ space and at the end a $20 \mathrm{~mm}$ space with the expression "Worst Pain" in Braille. To fulfil, the patient received all orientation in the first interview.

During the migraine crises the patients were orientated to put their distal phalanx of the left little finger on the first point on the scale (no pain reference point) and forefinger on the last point (worst pain reference point) and with distal phalanx of the forefinger of the right hand the patients marked with the nail on the line, the imaginable place where the pain was. After that, the patients marked the TAS they higlighted with the last point on the scale. Such procedure was repeated during all migraine attacks. The days that there were not crises they did not fulfil the form, but they highlighted with the nail the first point on the scale. The absence of a point, in the beginning or at the end, orientates the patient to fill the next line and so there was no risk of the same line be fulfilled twice.

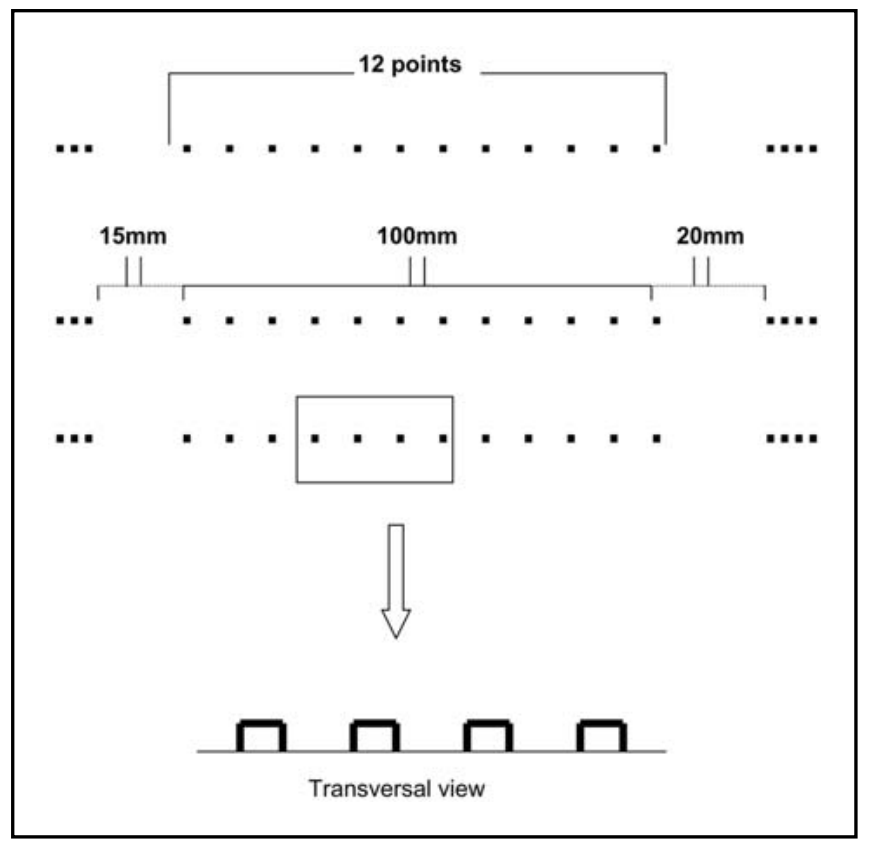

Fig 1. Tactile analogical scale. 


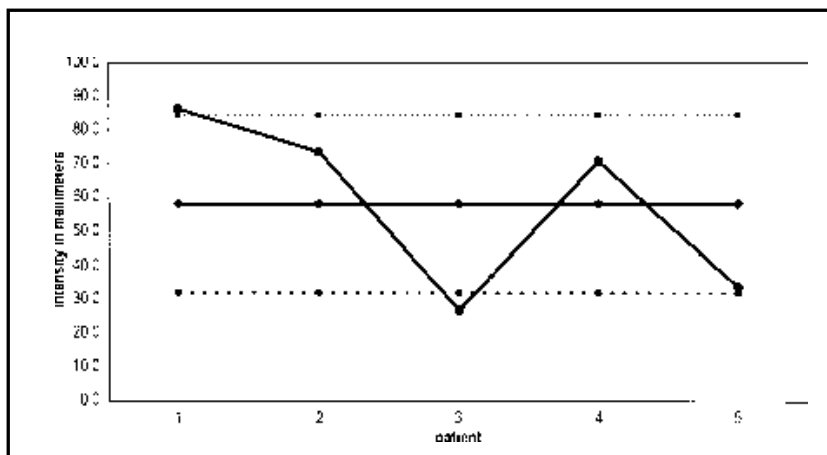

Graphic 1a. Measurement of the average intensity of the migraine attacks in the patients of the subroup $A(n=-5)$.

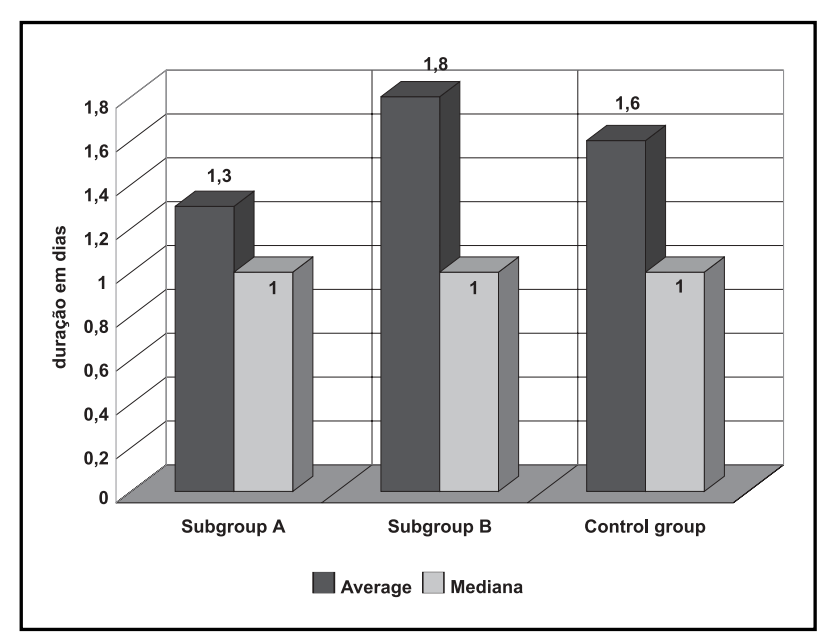

Graphic 2. Comparison between average of the duration and mediana duration (days) of the migraine attacks in the subgroup $A$ and $B$ and control. Average.

\section{Statistical analysis}

The statistic analysis was applied through Mann-Whitney test for the visual handicaped group and the control group. It was evaluated the confidence rate (95\%) for subgroups $A$ and $B$.

The study was approved by the Ethic Committee in Human Beings of the Hospital de Clínicas da Universidade Federal do Paraná.

\section{RESULTS}

The individual analysis of the attacks in each patients of the subgroup A was characterised by attacks of medium intensity $58.17 \pm 26.24 \mathrm{~mm}$ (Graphic 1 ). Observing collectively subgroup $A, 46$ attacks were evaluated with an average intensity of $56.49 \mathrm{~mm} \pm 31.19 \mathrm{~mm}$ with an average duration of $1.3 \pm 0.67$ days (Graphic 2 ). Subgroup B showed an average intensity of $55.79 \pm 18.32 \mathrm{~mm}$ (Graphic 1) their attacks. Observing collectively the attacks in this group, there were 45 migraine attacks with average

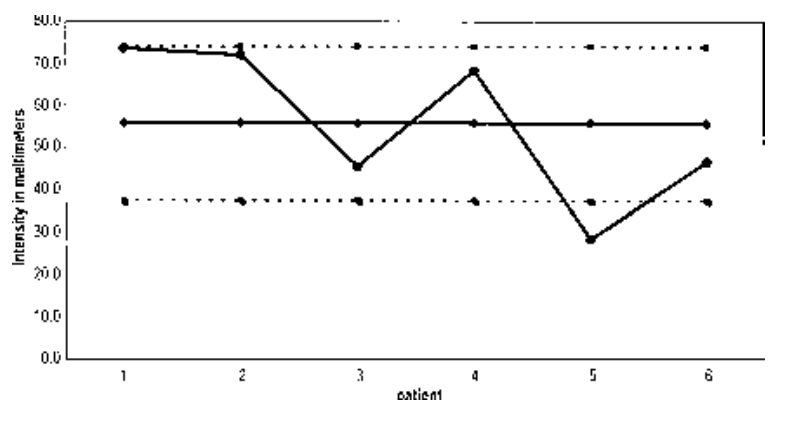

Graphic 1b. Measurement of the average intensity of the migraine attacks in the patients of the subgroup $B(n=6)$.

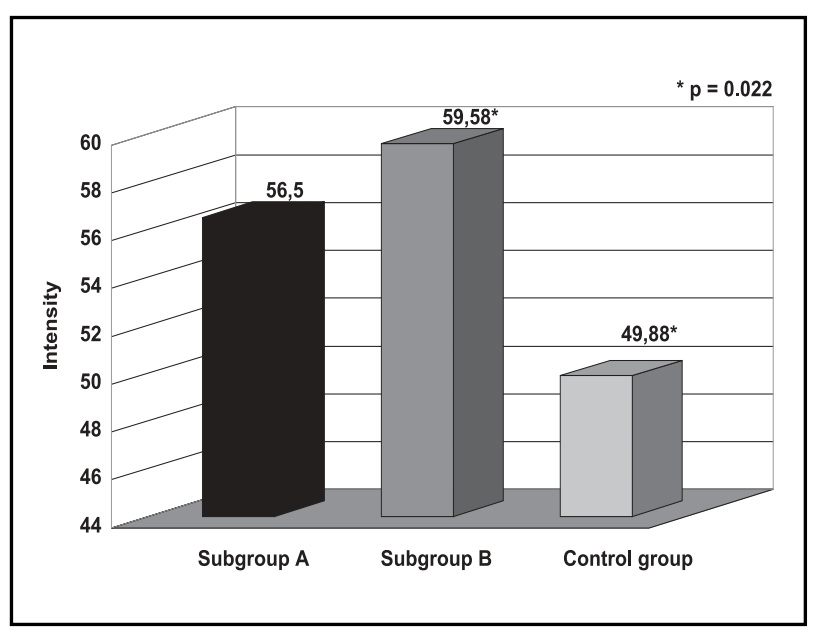

Graphic 3. Measurement of the intensity of the migraine attacks between subgroup $A, B$ and control.

intensity of $59.58 \pm 24.11 \mathrm{~mm}$. The average duration was $1.77 \pm 1.38$ days. In the control group, the migraine attacks average intensity individually was $47.88 \pm 17.06 \mathrm{~mm}$. The global analysis of all patient was consituted by 93 attacks with average intensity $49.88 \pm 27.36 \mathrm{~mm}$. The attacks average duration was $1.6 \pm 0,8$ days.

Analyzing the data with a confidence rate of $95 \%$ for the subgroup A headache average intensity, we got the minimum value of $25.6 \mathrm{~mm}$ and the maximum value $90.8 \mathrm{~mm}$, and all patients showed attacks average intensity in this range. When we analysed the same characteristics in subgroup $B$, we can realize a minimum value $36.6 \mathrm{~mm}$ and a maximum value $75 \mathrm{~mm}$. In this group, a patient showed his average attacks below the confidence rate $(28.5$ $\mathrm{mm}$ ). However, this value could occurred by the little sample that was used for the study, not invalidating the statistics analyses. 
Comparing subgroups $A$ and $B$ according to their migraine attacks intensity in each patient, there was not significant statistic difference $(p=0.417)$. When comparing subgroup $A$ and control, also there was not a significant statistic difference $(p=0.385)$. The same happened when we analysed subgroup $B$ and the control group $(p=0.877)$. When we analysed the headache attacks duration without distinction of patient, there was not statistic difference for all groups studied.

When comparing the migraine crises average intensity between subgroups $A$ and $B$, there was not statistic difference $(p=0.787)$ for crises average intensity ( $56.5 \mathrm{~mm}$ versus $59.58 \mathrm{~mm}$ ). When subgroups A and control group were compared, there was not a significant statistic difference $(p=0.238)$. However, analysing subgroups $B$ and the control group we got a significant statistic value $(p=0.022)$ (Graphic 3).

\section{DISCUSSION}

The outer layer of the cerebral cortex is divided into several areas specialised in detecting and processing sensory signals from the eyes and ears and from receptors for touch and nociceptors. Evereday experience illustrates that, despite their differences, the sensory regions of the cortex must be co-operating with each other by integrating the sensory stimuli they receive from the outside world ${ }^{5}$. The integration among different sensory forms (visual, tactile and nociceptive) is processed through multimodal neurones and through cortical association "cross modal".

The multimodal integration in the neurone cells is a physiologic characteristic that occurs in some cortical structures. Areas containing bimodal neurones are located in the ventral premotor area, putamen, poscentral gyro, parietal area $7 \mathrm{~b}$ and ventral intraparietal ${ }^{6}$. These neurons can respond to tactile and visual stimuli simultaneously. This way the visual stimulus reaches the visual receptive field and extend secondarily to the tactile receptive field at the same time and vice-versa ${ }^{7,8}$. The bimodal cells show visual and tactile receptive fields distributed predominantly on the face, arm and parts of the superior trunk. With the integration between tactile and visual perception the human brain structures visual-spatial maps for the hand, arm and face ${ }^{9-11}$. The visual spatial perceptive integration for the face involves the optic nerve and trigeminal nerve. The total visual loss produces an adaptation in this via, promoting exclusivity in the tactile afferences for the bimodal neurones. Recently studies have showed that the trigeminal nociceptive sensibility also is influenced by the lost of visual afferences and so increasing the threshold of the perception pain in the cases where the patient lost the vision before 14 years old ${ }^{12}$.

Studies that analyze the changes ocurred in the cerebral cortex of the visual handicapped demonstrate that, although this patient did not receive visual afference, the primary and secondary visual cortex anatomy remained unchangeable ${ }^{13}$. So cerebral function, when it is analysed through photon emission computed tomography (SPECT), positron emission tomography (PET) and functional resonance nuclear magnetic (fRNM), demonstrated a recruiting of the occipital cortex for other neurones commands, including other sensitive forms as tactile and auditory ${ }^{14-18}$. The metabolic activity of the visual cortex in blind people does not show any difference in the cerebral blood flow, glucose metabolism and oxygen consumption in relation to the control group with no visual deficiency, demonstrating electrical activity in the area ${ }^{19-21}$.

This cortical plasticity does not occur just in the occipital cortex but also in other areas analysed (motor, sensory, tactile), being dependent of frequency and using time of the analysed area ${ }^{22-24}$. This plasticity "cross modal" probably helps to improve the tactile perception abilities in blind people ${ }^{16,25,26}$. The characteristic of the plasticity is represented by an alteration in the cortical topography and an increase of the cortical representation in the analysed area, due to an increase in the peripheral afference associated to an adaptive phenomenon of the cortical representation of the organisation ${ }^{24,27}$.

As a visual experience is important for a precocious organization of the visual cortex, a possible re-organization will be associated directly with the visual loss time ${ }^{28,29}$. It is known that the re-organization of the occipital cortex is interrupted at about 14 years old ${ }^{30}$. The age group coincides with the puberty and is associated with a reduction of supernumerary synapses inside the visual cortex ${ }^{31,32}$. Another associative via that occurs between the somatosensory cortex (touch) and visual cortex is through "crossmodal" mechanism. This crossmodal effect arises even if the tactile cues are tasked irrelevant and do not predict the location of the visual targets, suggesting an exogenous (stimulus driven) attentional mechanism ${ }^{32}$. Recent studies that analysed the effective connectivity suggest that tactile input to the somatosensory cortex may influence the visual cor- 


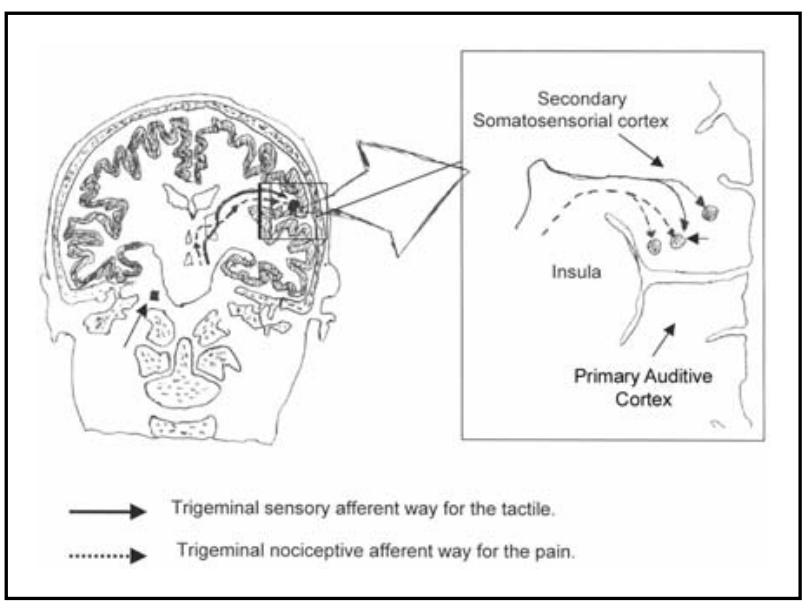

Fig 2. Confluences between tactile sensitiveway and nociceptiveway.

tex via back projection through association areas in the parietal lobe ${ }^{33}$. Such back-projections according to recent theorical proposals may play a crucial role in crossmodal links in spatial attention ${ }^{34}$. The existent relation between primary and secondary visual cortex and the tactile sensory cortex is justified by the bimodal neurones and crossmodal connections. The lost of the visual inputs to the occiptal cortex also influences the trigeminal nociceptive discrimination $^{12}$. It permits to draw a conclusion that the visual cortex is involved in other tasks that are not just visual, as reading in Braille, tactile and trigeminal nociceptive discrimination ${ }^{12,14,35}$.

These studies show that subjects totally blind, with visual loss before 14 years, show, in their migraine attacks, an average intensity superior to migraneous subjects without visual loss. We suggest that the increase of the cortical activity for a tactile sensibility could interfere on the cortical nociceptive modulation during the migraine attacks.

Recent studies show that the secondary somatosensory cortex is located on the superior edge of the Sylvian fissure as part of the front-parietal operculum (SII) (Figs 2 and 3) ${ }^{36}$. Studies using PET and fMRI after tactile stimuli in human beings, reveal an activation of multiple somatosensory areas that extend on the superior edge of the Sylvian fissure inside the retroinsular cortex and anterior insula ${ }^{37-39}$. Both of them, the parietal operculum and insula (placed on the opposite side of front-parietal operculum of the insula's sulcus) contains areas of somatosensory association (nociceptive and tactile) ${ }^{36}$.

The potential register evoked from stimuli utilising the laser suggest that the nociceptive area inside the parasylvian cortex is located deeply in the parietal

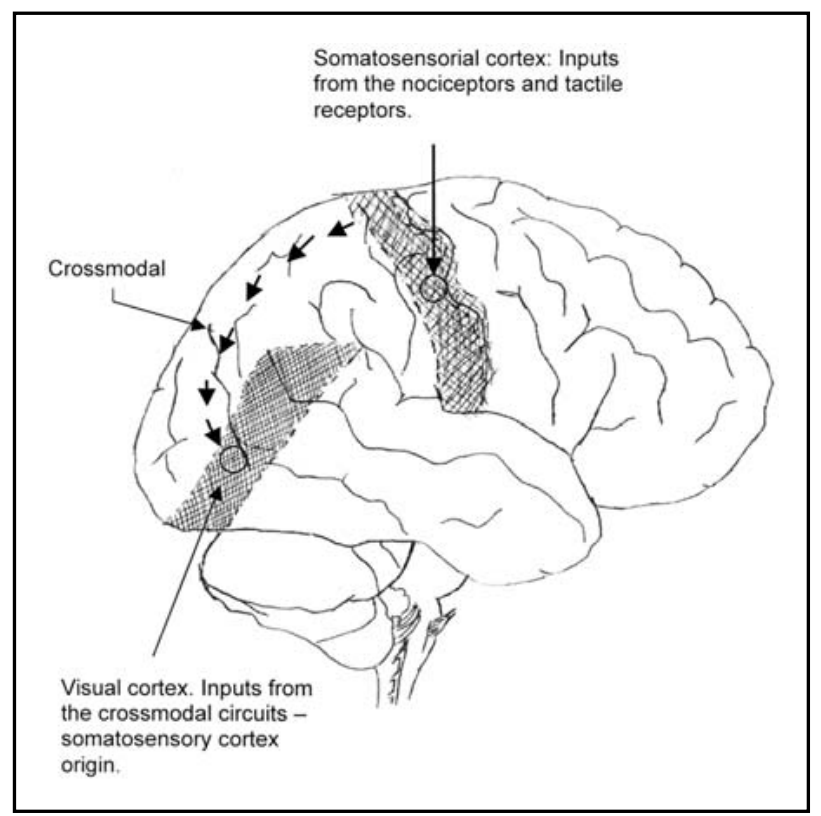

Fig 3. Graphic representation of the crossmodal mechanisms.

operculum surface. This area is next to the intermediate part between SII and insula ${ }^{36-40}$. One of the first electro-physiological studies that try to establish connections between the tactile and nociceptive sensibilities inside the cerebral cortex and posterior region of SII includes nociceptive and polisensory neurones. However SII anterior portion is only associated to tactile neurons ${ }^{41}$. An extensive study trying to codify the nociceptive neurones properties in monkeys has identified a greater number of cells inside the posterior parietal region $7 \mathrm{~b}$ than in the region $\mathrm{SII}^{42}$. Studies utilizing high-resolution $\mathrm{fMRI}$ after vibratactile and painful thermos stimuli showed only an activation in common (painful nociceptive sensibility and tactile sensibility) of $30 \%$ of the neurones located inside the parietal operculum ${ }^{43}$.

This study reveals that migraneous blind subjects before 14 years old showed an average intensity of their crises higher than the migraneous subjects with partial visual loss and normal migraneous ones. The duration and frequency of their attacks did not suffer any interference by the visual loss. Probably the patients with partial loss, keeping their visual afferences, incapacitate the neuroplasticity on the tactile and nociceptive sensibility. We concluded that the visual loss can interfere directly or indirectly on the nociceptive mechanisms of the migraneous patients, and so determining a greater intensity in their attacks. The study can not establish the real nature of these findings. However, we speculate that the nociceptive cerebral neuroplasticity was interfered after losing the visual afferences. The relation be- 
tween visual, tactile and nociceptive afferences on the bimodal neurones at the parietal operculum, parietal region, parietal posterior or any other region of the nociceptive cortex must be established from the study involving fMRI or PET.

\section{REFERENCES}

1. Scott PJ, Huskisson EC. Measurement of functional capacity with visual analogue scales. Rheumatol Rehab 1977;16:257-258.

2. Piovesan EJ, Lange MC, Werneck LC, Kowacs PA, Piovesan LM. Comparative study between visual analogue scale (VAS) and tactile analogue scale (TAS), a new scale. Cephalalgia 2000;20:323.

3. Headache Classification Committee of the International Headache Society. Classification and diagnostic criteria for headache disorders, cranial neuralgia, and facial pain. Cephalalgia 1988;8(Suppl7):1-96.

4. OMS. Classificação estatística internacional de doenças e problemas relacionados a saúde CID 10. 4.Ed. São Paulo: EDUSP, 1997;1:442-443.

5. Gelder B. More to seeing than meets the eye. Science 2000;289:11481149.

6. Rizzolatti G, Luppino G, Matelli M. The organization of the cortical motor system: new concepts. Eletroencephalogr Clin Neurophysiol 1998;106:283-296.

7. Iriki A, Tanaka M, Iwamura Y. Coding of modified body schema during tool use by macaque postcentral neurones. Neuroreport 1996; 7:2325-2330.

8. Rizzolatti G, Luppino G, Matelli M, Gentilucci M. Afferent properties of periarcuate neurons in macaque monkeys: II. Visual responses. Behav Brain Res 1981;2:146-163.

9. Di Pellegrino G, Làdavas E, Famè A. Seeing where your hands are. Nature 1997;388:370.

10. Làdavas E, Zeloni G, Farnè A. Visual peripersonal space centred on the face in humans. Brain 1998;121:2317-2326.

11. Farnè A, Pavani F, Meneghello F, Làdavas E. Left tactile extinction following visual stimulation of a rubber hand. Brain 2000;123:2350-2360.

12. Piovesan EJ, Lange M C, Pacheco CG, Fameli H, Kowas PA, Werneck LC. Influence of visual loss on the threshold of pain perception. Neurology 2001;56(Suppl 3):A65.

13. Breitenseher M,Uhl F, Wimberger DP, Deecke L, Trattnig S, Kramer J. Morphological dissociation between visual pathways and cortex: MRI of visually-deprived patients with congenital peripheral blindness. Neuroradiology 1998;40:424-427.

14. Sadato N, Pascual-Leone A, Grafman J, Deiber MP, Ibañez V, Hallet M. Neural networks for Braille reading by the blind. Brain 1998;121: 1213-1229.

15. Sadato N, Hallet M. fMRI occipital activation by tactile stimulation in a blind man. Neurology 1999;52:423.

16. Cohen LG, Celnik P, Pascual-Leone A, et al. Functional relevance of cross-modal plasticity in blind humans. Nature 1997;389:180-183.

17. Kujala T, Huotilainen M, Sinkkonen J, et al. Visual cortex activation in blind humans during sound discrimination. Neurosci Lett 1995;183:142-146.

18. Piovesan EJ, Lange MC, Minguetti G, et al. Análise estrutural e funcional do lobo occipital em pacientes cegos totais: perda antes dos 14 anos. Arq Neuropsiquiatr 2000;58 (Supl-2):43.

19. Ishikawa N, Nishua K, Satou M, Takeda T, Itai Y. Study on the primary cortex of visually impaired subjects by means of 123-I-IMP SPECT and MRI. Ann Nucl Med 1995;9:105-108.

20. De Volder AG, Bol A, Blin R, et al. Brain energy metabolism in early blind subjects: neural activity in the visual cortex. Brain Res 1997; 750:235-244.
21. Wanet-Defalque MC, Veraart C, De Volder A, et al. High metabolic activity in the visual cortex of early blind human subjects. Brain Res 1988;446:369-373.

22. Pascual-Leone A, Wassermann EM, Sadato N, Hallet M. The role of reading activity on the modulation of motor cortical outputs to the reading hand in Braille readers. Ann Neurol 1995;38:910-915.

23. Pascual-Leone A, Cammarota A, Wasserman EM, Brasil-Neto JP, Cohen LG, Hallet M. Modulation of motor cortical outputs to the reading hand of Braille readers. Ann Neurol 1993;34:33-37.

24. Sterr A, Müller MM, Elbert T, Rockstroh B, Pantev C, Taub E. Perceptual correlates of changes in cortical representation of fingers in blind multifinger Braille readers. J Neurosci 1998;18:4417-4423.

25. Sunanto J, Nakata $H$. Indirect tactual discrimination of heights by blind and blindfolded sighted subjects. Perceptual Motor Skills 1998;86:383-386.

26. Delbert E, Kraut M, Kremen S, Hart J. Neural pathways in tactile object recognition. Neurology 1999;52:1413-1417.

27. Werring DJ, Bullmore ET, Toosy A, et al. Recovery from optic neuritis is associated with a change in the distribution of cerebral response to visual stimulation: a functional magnetic resonance imaging study. J Neurol Neurosurg Psychiatry 2000;68:441-449.

28. Hubel DH, Wiesel TN, Functional architecture of macaque monkey visual cortex. Proc R Soc Lond Biol Sci 1977;198:1-59.

29. Price DJ, Ferrer JM, Blakemore C, Kato N. Postnatal development and plasticity of corticocortical projections from area 17 to area 18 in the cat's visual cortex. J Neurosci 1994;14:2747-2762.

30. Cohen LG, Weeks RA, Sadato N, Celnik P, Ishi K, Hallet M. Period of susceptibility for cross-modal plasticity in the blind. Ann Neurol 1999;45:451-460.

31. Bourgeois JP, Rakic P. Changes of synaptic density in the primary visual cortex of the macaque monkey from fetal to adult stage. J Neurosci 1993;13:2801-2820.

32. Veraart C, De Volder AG, Wanet-Defalque MC, Bol A, Michel C, Goffinet AM. Glucose utilization in human visual cortex is abnormally elevated in blindness of early onset but decreased in blindness of late onset. Brain Res 1990;510:115-121.

33. Macaluso E, Frith CD, Driver J. Modulation of human visual cortex by crossmodal spatial attention. Science 2000;289:1206-1208.

34. Driver J, Spence C. Crossmodal attention. Curr Opin Neurobiol 1998; 2:245-253.

35. Sathian K, Zangaladze A, Hoffman JM, Grafton ST. Feeling with the mind's eye. Neuroreport 1997;8:3877-3881.

36. Treede RD, Apkarian AV, Bromm B, Greenspan JD, Lenz FA. Cortical representation of pain: functional characterization of nociceptive areas near the lateral sulcus. Pain 2000;87:113-119.

37. Burton H, Videen TO, Raichle ME. Tactile-vibration-activate foci in insular and parietal-opercular cortex studied with positron emission tomography: mapping the $2^{\text {nd }}$ somatosensory area in humans. Somatosens Motor Res 1993;10:297-308.

38. Hodge CJ, Huckins SC, Szeveryl NM, Fonte MM, Dubroff JG, Davuluri K. Patterns of lateral sensory cortical activation determined using functional magnetic resonance imaging. J Neurosurg 1998;89:769-779.

39. Disbrow E, Roberts T, Krubitzer L. Somatotopic organization of cortical fields in the lateral sulcus of homosapiens: evidence for SII and PV. J Comp Neurol 2000;418:1-21.

40. Greenspam JD, Lee RR, Lenz FA. Pain sensitivity alterations as a function of lesion location in the parasylvian cortex. Pain 1999;81:273-282.

41. Whitsel BL, Petrucelli LM, Werner G. Symmetry and connectivity in the map of the body surface in somatosensory area II of primates. J Neurophysiol 1969;32:170-183.

42. Dong WK, Chudler EH, Sugiyama K, Roberts VJ, Hayashi T. Somatosensory, multisensory, and task-related neurons in cortical area $7 \mathrm{~b}$ (PF) of unanesthetized monkeys. J Neurophysiol 1994;72:542-564.

43. Gelnar PA, Krauss BR, Sheehe PR, Szeverenyl NM, Apkarian AV. A comparative fMRI study of cortical representations for thermal painful, vibrotactile, and motor perfomance tasks. Neuroimage 1999;10:460-482. 